\title{
ORGANIZATION AND FIRM PERFORMANCE IN THE CZECH REPUBLIC
}

\author{
Štěpán Jurajda, Juraj Stančík*
}

\begin{abstract}
:
Many economic analyses use employer-employee data to compare wage and productivity differentials across demographic groups. We apply this approach to assess the importance of 'organizational' workers, i.e., managing and marketing personnel. The estimates based on 2000-2006 Czech worker-level data augmented with company balance sheet information suggest that these workers are important for company performance and that they are fairly rewarded for their relative productivity in terms of their relative pay. Foreign-owned companies feature higher shares of such workers who are more productive in these firms (relative to other employees) compared to domestically owned companies.
\end{abstract}

Keywords: linked employer-employee data, productivity differentials, organizational workers JEL classification: O30, O32, O40, O52, R11

\section{Introduction}

Productivity is a firm-level phenomenon. If unobservable person-specific productivity varies systematically with the demographic structure of a firm's workforce, then one ought to be able to detect such productivity differentials when analyzing observable firm-level productivity. The same argument applies to wage differentials, where one can typically verify that, indeed, wage gaps across demographic groups estimated using worker-level data can be replicated using firm-level information as Hellerstein, Neumark and Troske (1999) (hereafter HNT) do. Hence a growing literature studying the importance of the workforce demographic structure for firm productivity and wage levels. ${ }^{1}$ By comparing productivity and wage differentials, such work can answer discrimination inquiries (unlike the estimation of wage functions alone) and test theories of wage formation; in particular, in a competitive spot market, wage and productivity differentials ought to be equal across worker types.

* CERGE-EI, Charles University Prague and Academy of Sciences of the Czech Republic, Politických věznů 7, Prague 11121, Czech Republic (stepan.jurajda@cerge-ei.cz).

This paper was part of the Inno-drive Project financed by the EU $7^{\text {th }}$ Framework Programme, No. 214576. The authors would like to thank Jan Hanousek, the Ministry of Labour and Social Affairs of the Czech Republic and Trexima Ltd. for data access and Vladimír Smolka of Trexima for extremely helpful data and assistance. Comments from the participants in several Inno-drive Project workshops are gratefully acknowledged. Jurajda is also affiliated with CEPR, London, IZA, Bonn, and WDI, Ann Arbor. Stančík is Scientific Fellow at IPTS (DG JRC, European Commission) in Seville.

1 Other than HNT, see, e.g., Ilmakunnas and Maliranta (2005) or van Ours and Stoeldraijer (2010), who summarize over ten other similar recent studies. See Parotta et al. (2010a) for a structural approach. 
Another line of empirical work attempts to study the importance of firm-specific R\&D investments and 'new' forms of intangible capital including 'organizational capital' (e.g., Brynjolfsson, et al., 2002; Bontempi and Mairesse, 2008). This work is motivated by the growing importance of these hard-to-measure inputs into production and productivity growth, in particular in services and in product-development, design and marketing areas. Similar to worker-level productivity, firm-level 'organizational capital' remains an elusive object, even if one did agree on its definition. ${ }^{2}$

One easy way of approximating a firm's investment in its organizational structure is to ask about the share of the firm's workforce in organization-related occupations in management and marketing. (The occupational structure of employment being observable in widely available matched employer-employee data.) Such strategy is in line with the notion that expenditures on organizational development provide useful information on this input into the production and innovation process (Corrado, Hulten, 2010). Assuming that investment in 'organizational' intangibles occurs in people (i.e., that technology is labour-augmenting) also allows one to quantify the effect of such investment in intangibles on company performance. To do so, one can apply the methodology developed by HNT for studying the effects of company demographic structure to studying the impacts of its occupational composition. In particular, one can ask about the relative productivity of 'organizational workers' as well as their relative pay. Surely, information on such expenditures and their productivity value is a useful ingredient of any broader and more ambitious evaluation of company 'organizational capital'.

Unfortunately, the estimation (and interpretation) of company production functions is a notoriously difficult enterprise (Griliches, Mairesse, 1998). In particular, much like other production inputs, the observed choices of 'organizational investments' are likely to be endogenous, presenting challenges for the estimation of their effects. Consider the share of a firm's workforce employed in 'organizational' occupations. The denominator of this measure, i.e., total employment or hours, may be positively correlated with productivity shocks, leading to a downward bias in a regression coefficient of this share. Furthermore, such a share measure of organizational inputs into production could be misleading (measured with error) as one can easily imagine a firm with fewer high-quality high-wage 'organizational' workers performing better than another firm with a high share of low-quality organizational employees. Hence, in order to consistently estimate the importance of organizational inputs, such as the share of organization employees, it is useful to be able to rely on an exogenous source of variation in such inputs.

In this paper, we rely on the fact that most organization-related workers have a tertiary education degree and use the historical location of college education to provide such 2 See Section 2 for a discussion of various definitions and of macroeconomic accounting evaluations
of the importance of these 'new' intangibles. 
exogenous source of variation in the company share of 'organizational' workers. ${ }^{3}$ Specifically, we use the variation in NUTS-4 area college-education production as of the end of central planning in the Czech Republic to predict the share of 'organizational' workers in Czech firms in 2005, assuming that the location of colleges under communism is effectively orthogonal to current market-economy productivity shocks. ${ }^{4}$ Our cross-sectional evidence can be interpreted as corresponding to a 'steadystate' allocation of intangibles driven by slow-changing external forces. The analysis is based on matched employer-employee data, which provide information on shares of workers in 'organizational' occupations, augmented with balance-sheet information on various performance indicators at the company level.

In order to interpret our productivity effect estimates as corresponding to the impact of investment in 'organizational' intangibles (in people), one must separate from the company performance data the effect of investing in workers who possess high levels of general human capital. In a subset of our analysis we therefore control for worker human-capital levels. All of our analysis also conditions on the company level of R\&D.

We define a broad group of 'organizational' workers, which forms about one tenth of firm workforce on average and find this share to be slightly increasing over time and somewhat higher in foreign-owned green-field investment companies. Perhaps not surprisingly, the relative productivity of 'organizational' workers we uncover is large, testifying to the importance of this particular kind of production input. We also find the wage and marginal productivity of organizational workers (relative to a reference group) to be broadly similar in our Czech data. The estimated importance of 'organizational' workers for company value added and staff costs is very sensitive to the source of variation used in the estimation; in particular, focusing on variation induced by the historical location of colleges, both relative productivity and pay increase up to three fold. When we isolate the part of the relative productivity of 'organizational' workers due to 'organizational' investments, as opposed to general human capital investments, we obtain estimates that are quantitatively similar to those recently obtained by Ilmakunnas and Piekkola (2010) with Finnish data. 'Organizational' workers appear about 50\% more productive than the rest of the company workforce.

The paper is structured as follows. The next section covers the background. Our estimation strategy is explained in Section 3. The fourth section contains the data description. The empirical results are presented in the fifth section. The last section concludes.

3 See Moretti (2004) or Jurajda and Terrell (2009) for studies of locality-specific human capital spillovers based on the same source of variation in the context of the U.S. and several postcommunist economies, respectively. See Parotta et al. (2010b) for a related study of firm innovation.

4 Of course, this argument assumes not only that college location is external to the non-observables driving company performance, but also that company location itself is exogenous - an issue we explore empirically below. 


\section{Background}

In this section, we provide a brief overview of the existing international work on 'organizational capital' and then discuss background facts and available research from the Czech Republic on two key intangible inputs, namely R\&D and organizational inputs.

\subsection{Measuring 'Organizational Capital'}

It is often argued that intangible capital explains much of the gap between the balancesheet value of a company's tangible assets and its market value. Few doubt that the importance of intangibles for production and innovation has grown in recent decades as societies as well as individual companies are moving away from producing things and into providing services or developing and marketing products. ${ }^{5}$ International accounting standards struggle with the question of whether to capitalize or expense intangibles (see the references provided in Bontempi and Mairesse, 2008) and some innovative firms record accounting data in new formats that allow one to observe investment flows for various components of intangible capital including software, $R \& D$ and patenting costs, advertising and trademark-related costs, or costs related to organizational development.

Prescott and Visscher (1980) introduced 'organizational capital' as corresponding to management-related abilities in hiring, teamwork and human-capital buildup, i.e., 'organizational capital in people'. Miyagawa and Kim (2008) additionally stress the role of marketing personnel for company organizational capital. The value of organizational structure is, however, difficult to quantify. Other parts of the 'intangibles literature' focus on software, ICT and R\&D investments and assets. Indeed, R\&D expenditures have become the first type of intangibles to be included in the OECD's satellite GDP accounting and research in progress is trying to introduce methods for including other intangibles. Finally, several other studies in this literature highlight the role of firm-specific human capital (training) or brand equity (related to marketing).

Recent macroeconomic evaluations of the importance of such 'new' intangibles based on measuring related expenditures suggest that Central European economies (the Czech Republic, Slovakia and Hungary) have recently recorded the highest growth in the EU in the share of intangibles in GDP and also experienced the highest impact of intangibles on labour productivity growth during 1995 to 2005 (Jona-Lasinio et al., 2011). 'Organizational capital' is typically responsible for almost a third of the 'new' intangibles in these countries.

In the present study, we aim to complement these growth accounting exercises using micro-level evidence. We remain within the 'organizational capital in people' approach and measure the importance for company performance of organizational inputs, which we define in a particularly simple way. Corrado and Hulten (2010) summarize the literature measuring intangible and organizational input using company expenditures. The share of the firm's workforce in organization-related occupations in management and marketing

5 For example, McGrattan and Prescott (2008) estimate intangible capital stock in the U.S. to lie between 31 and $76 \%$ of the GDP. 
offers an easily observed approximation of a firm's investment in its organizational structure. It appears quite natural that in order to provide a full evaluation of the importance of 'organizational capital' one would like to know the relative productivity of 'organizational workers'. Estimating this productivity gap (relative to the pay gap) is the purpose of this paper.

\subsection{Czech R\&D and Managerial Compensation}

As discussed above, R\&D and organizational inputs have been highlighted as key contributions to productivity and innovation. Hence, any exploration of one of these intangibles should provide a good account of the other one, too. In this section, we briefly discuss basic available facts on the level of R\&D expenditures as well as the available research on the performance effects of $\mathrm{R} \& \mathrm{D}$ and managerial compensation.

The Czech Statistical Office (CSO) has been monitoring Czech R\&D expenditures since 1995. In total, Czech R\&D spending increased by more than $250 \%$ between 1995 and 2006, reaching almost CZK 50 bil. (about EUR 2 bil.) in 2006. This corresponds to a $63 \%$ increase of the R\&D share on GDP - the so-called R\&D intensity. An international comparison of R\&D expenditure levels (GERD) and their growth in Figure 1 implies that the Czech Republic is a leading country in the group of the 12 New Member States of the EU with R\&D intensity above that of Ireland, Portugal, Spain, Italy or Greece. On the other hand, the country's R\&D intensity is less than half of that of Sweden or Finland. As of 2006, the Czech Republic generated about a third of the aggregate R\&D expenditures of the 12 New Member States and about one percent of total EU-27 R\&D expenditures. This is in large part due to continuous growth in Czech R\&D expenditures that accelerated in 2005. In the EU, only four countries (the three Baltic countries and Romania) feature substantially higher average growth rates over our sample period ending in 2006.

The enterprise sector accounts for the highest share of Czech R\&D funding (over $50 \%$ ) and performance (over 60\%). ${ }^{6}$ However, the growth in R\&D spending over the last decade has occurred almost proportionally across all relevant sectors (including government, higher education, and private non-profit) and the funding structure of Czech $\mathrm{R} \& \mathrm{D}$ is now quite similar to that of the EU-27.

An industry-level division of business R\&D expenditures can be found in Table 1 . The comparison here is made between the years 2000 and 2006, as well as between the group

6 In comparison, the share of the enterprise sector on R\&D in a median EU-27 country is $50 \%$ for funding and $52 \%$ for performance. Hence, despite the prevailing local general wisdom, the R\&D spending in the country as of 2007 was quite comparable to that of the EU not only in terms of levels, but also in its structure.

7 With the exception of a smaller share of R\&D funding coming from abroad. These comparisons are based on Eurostat R\&D figures. Also, per capita Business Expenditures on R\&D (BERD) in euro suggest that the gaps in R\&D spending expressed in a common currency are wider than those expressed in GDP shares (in Figure 1). 
of all companies and the group of companies with at least $50 \%$ of foreign capital. While in 2000 the single leading sector in R\&D expenditure was the automotive industry, spending $3.6 \%$ of its size, by 2006 it was overtaken by manufacture of computer, electrical and optical equipment. As can be seen in the next two columns, the rise in the R\&D expenditures in the latter industry, jointly with that of the petrochemical industry, is in large part due to foreign-owned companies. Indeed, given the massive foreign direct investment (FDI) inflows the Czech Republic enjoyed around the time of its EU accession, ${ }^{8}$ over $70 \%$ of manufacturing ( $34 \%$ of service-sector) R\&D expenditure came from foreign-owned companies as of 2006.

In sum, the Czech Republic has enjoyed enormous growth of R\&D spending since the start of pro-market reforms and this growth has become particularly pronounced after it joined the EU. R\&D is thus likely to be one of the key drivers of growth. This intuition is underscored by the growing importance of foreign-owned companies, which are consistently more productive than domestically owned firms, as Sabirianova et al. (2005) demonstrate for the Czech Republic and Russia. It is therefore not surprising that there is growing amount of research studying several aspects of R\&D in the Czech Republic.

Specifically, Kinoshita (2000) or Damijan et al. (2003a) are examples of studies using data from the late 1990s that study R\&D and FDI spillovers and productivityenhancing effects. The role of foreign ownership for cooperation on innovation with non-affiliated partners is explored in Srholec (2009), who implies that foreign affiliates have a significantly higher propensity to venture into such cooperation, which lends support to the argument that foreign ownership lubricates flows of knowledge across national borders.

Compared to the extensive research on ownership and R\&D productivity effects, there is less work studying the internal incentive and organizational structure of Czech firms (including the incentives for supporting R\&D or 'organizational' intangibles). Expenditures on management staff are not routinely compared across countries in a harmonized fashion and studies measuring the effects of company organizational structure are almost always constrained to a single country. The Czech literature on managerial compensation is particularly brief: Eriksson (2005) shows that lagged levels of Czech company performance influence the growth of CEO compensation, implying the presence of incentives for top management in Czech firms to increase profitability. However, in contrast to a large literature on executive pay in mature market economies, changes in performance apparently do not give rise to changes in pay. ${ }^{9}$

8 In the Czech Republic, large FDI inflows started only after the mass privatization programs were completed. Benefiting from investment subsidies and tax breaks introduced in 1997, Czech FDI inflows rose from below 3\% of GDP in 1996 to 1997 to over 10\% during 1999 to 2002. As a result, Czech FDI stock per capita reached EUR 5,256 in 2005, which compared favourably with the 2005 FDI stock in Slovakia $(2,721)$ or Poland $(2,070)$.

9 Other available studies, such as Jurajda and Paligorova (2009) ask only about the structure of managerial compensation, but do not explore its performance links. 


\section{Estimation Approach}

In this paper, we follow the approach proposed by HNT, who, based on assuming perfect substitutability between different types of workers, estimate a production function involving not only aggregate measures of capital and labour inputs, but also controlling for the shares in employment (or hours worked) of different worker types in order to allow for their marginal productivities to differ. With only two types of workers, a qualityadjusted labour input $L^{*}$ can be expressed as $L^{*}=L[1+(\varphi-1) s]$, where $L$ stands for a total employment (or hours) measure, $s$ represents the share in that total labour input measure of a given type of workers ('occupational' workers in our case), and $\varphi$ captures the marginal productivity of this worker group relative to that of the reference groups of all other workers.

More precisely, we use the Cobb-Douglas production function and a linear approximation to the HNT original approach with the quality-adjusted labour input $\ln L^{*}$ approximated as $L+(\varphi-1) s .{ }^{10}$ In sum, we estimate the following production function:

$$
\ln V A_{i t}=\alpha_{0}+\alpha_{1} \ln L_{i t}+\alpha_{2} \frac{O_{i t}}{L_{i t}}+\alpha_{3} R N D_{i t}+\alpha_{4} T F A_{i t}+\varepsilon_{i t},
$$

where $V A_{i t}$ is the value added of firm $i$ in year $t, L_{i t}$ denotes total work hours, $O_{i t}$ denotes total work hours of organizational workers, $R N D_{i t}$ is a firm-specific R\&D capital, $T F A_{i t}$ denotes tangible fixed assets, and $\varepsilon_{i t}$ is an error term. For example, a finding of $\varphi=\frac{\alpha_{2}}{\alpha_{1}}+1=1.2$ would imply that organizational workers are $20 \%$ more productive than other workers (the reference worker group). The fact that we estimate a value-added version of the production function allows us to sidestep the issue of endogeneity of materials that would be present in an output version and it enhances the comparability of the dependent variable across industries. In order to compare relative productivity differentials to relative wages (staff costs), HNT estimate the production function jointly with a regression for the company staff costs (assuming equal relative wages across firms). In the same spirit, and for the sake of comparability with equation (1), we estimate the following equation:

$$
\ln S C_{i t}=\beta_{0}+\beta_{1} \ln L_{i t}+\beta_{2} \frac{O_{i t}}{L_{i t}}+\beta_{3} R N D_{i t}+\beta_{4} T F A_{i t}+\varepsilon_{i t},
$$

where $S C_{i t}$ is the staff costs of firm $i$ in year $t$. One can then test for whether the coefficient on the share of a worker group in employment from the wage regression equals the ratio of the corresponding coefficient from the value added regression divided by the total employment coefficient from the same regression, i.e., whether $\beta_{2}=\frac{\alpha_{2}}{\alpha_{1}} \cdot{ }^{11}$ All of the

10 This approximation has been recently applied by, e.g., Ilmakunnas and Maliranta (2005) or Haltiwanger, Lane and Spleter (1999).

11 See Ilmakunnas and Maliranta (2005) and the references therein for other such tests. Both HNT and Ilmakunnas and Maliranta (2005) suggest that estimation of the production function is quite robust with respect to the details of the estimation method, the perfect substitutability assumption, data-quality issues, alternative measures of capital inputs, or industry flexibility in the estimation of the production function. 
estimated equations also control for an interaction of year and industry (1-digit NACE sectors) indicators.

Clearly, equations (1) and (2) do not distinguish whether productivity (wage-bill) effects correspond to the impact of investment in 'organizational' intangibles (in people) or simply to employing a higher share of workers who possess high levels of general human capital. First, we note this issue does not affect the quantitative validity of the comparison of relative productivity of 'organizational workers' with their relative pay, as long as workers are fairly rewarded for their general human capital - a save assumption. In absence of general human-capital controls, we cannot separate the part of relative productivity and relative pay of 'organizational' workers that is due to their 'organizational' intangibles as opposed to their companies' level of general skills, but we can still ask whether this group of workers is rewarded in a spot labour market according to their productivity.

Second, in order to provide a measure of the effect of company-specific 'organizational' intangibles, i.e., a clearer interpretation for productivity estimates from equation (1), we separately estimate both equations (1) and (2) with additional controls for worker general education levels. Similarly, we use worker-level wage data to shed more light on this issue by comparing the $\beta_{2}$ coefficient estimated from firm-level staff-costs regressions with a similar parameter estimated from Mincerian log-wage regressions. While our main goal is to compare estimates of wage and productivity differentials with company-level data, we thus also provide worker-level evidence on wage differentials controlling for other worker demographics including human capital controls. This exercise is interesting in its own right. Further, it allows us to differentiate between two explanations for the estimates from firm-level regressions. Specifically, as the identification of productivity differentials is based on an across-firm comparison, the firm-level data do not allow one to generate conclusive evidence on whether a higher productivity of organization-related workers comes from a higher share of such workers in more productive firms or instead from the higher productivity of organizational workers within firms. Using individuallevel wage data, one can shed light on this issue as well. A finding of significant positive wage gaps within firms would support the latter interpretation of a positive $\alpha_{2}$.

It is well known that the estimation of production functions may involve simultaneity biases (as argued, e.g., by Griliches and Mairesse, 1997). This intuition is confirmed within the recent literature on demographic productivity differentials by Aubert (2003) who suggests that the inputs endogeneity biases can be large. While panel data does allow one to remove the simultaneity driven by permanent (time constant) shocks, minimizing the impact of temporal simultaneity is more difficult, especially with panel data as short as we have. ${ }^{12}$ Yet, temporal endogeneity is likely to be present when companies react to

12 Not only are our data too short for estimating a dynamic GMM model, the widely used technique of Olley and Pakes (1996) requires information about investment, materials, or energy inputs, which are not available in our data. The alternative estimation method of Levinsohn and Petrin (2003) is also not practical given the short time-span of our data. We note in this regard in the context of another study that Galuscak and Lizal (2011) have shown using Czech data that capital measurement error has a substantial effect on estimated TFP, which suggests the need for future studies to use longer samples, once these become available. 
productivity shocks adjusting their share of organizational workers. Similarly, one may be concerned that relying on within-firm variation exacerbates the measurement error bias stemming from, e.g., misclassification of occupations.

Hence, in this paper we employ a cross-sectional identification strategy that relies on an exogenous source of variation in the share of organizational workers in a company determined through (pre-determined) company location. In particular, we instrument for the share of organizational workers using the variation in NUTS-4 area college-education production inherited from central planning (measured as of 1991), assuming that the location of colleges under communism is effectively orthogonal to current market-economy productivity shocks, at least conditional on the current regional industry structure. ${ }^{13}$ The instrument (denoted coll91) predicts the share of organizational workers strongly.

However, once we include in the estimation of equations (1) and (2) additional controls for general human capital levels, we would need two instruments for two endogenous variables, but only have one. We therefore present two sets of main specifications: First, we instrument for the share of 'organizational' workers (and omit the generalhuman-capital controls from the regression). We use these results to ask about whether 'organizational' workers are rewarded fairly for their relative productivity, whether it comes from 'organizational' intangibles or general-skills. ${ }^{14}$ Second, we estimate non-instrumented specifications controlling for general human capital at the company level. This specification provides a quantification of company-level 'organizational' intangibles but suffers from potential measurement error and endogeneity biases.

13 Since a significant share of organization-related workers have a tertiary degree, using the historical local-college-degree-production instrument to predict the share of all organizational workers results in large part in predicting the share of these workers with a college degree.

Our goal, however, is to assess the sensitivity of the cross-sectional estimate to using an exogenous source of variation. In a robustness check we therefore first estimate the relative productivity of organizational workers with a college diploma and then instrument this particular measure of organizational inputs. The increase in the value of the coefficient is actually fully similar to that based on using all organization-related workers.

14 In an alternative approach, Crepon et al. (2002) propose to replace the share of a worker group in company employment by its share in company total cost whilst adding the logarithm of company average wage to the list of regressors. This approach has at least two advantages over the HNT technique and one major disadvantage. First, it generates a simple test of the equality of relative wages and productivities - the t-test on the coefficient of the wage bill share. Second, it assumes only that the ratio of productivity to wages is constant across firms in contrast to the HNT approach, which assumes that both wage differentials and productivity differentials are constant across companies. This is important in our case because a potential criticism of using cross-firm variation in the share of organizational workers as a proxy for the firms' organizational investment is that there may be a systematic measurement error where a firm with fewer high-quality highwage organizational workers performs better than another firm with a high share of low-quality organizational employees. (In other words, the HNT approach provides only a market-wide comparison of productivity and wage differentials, not a firm-specific one.) Unfortunately, the likely strong endogeneity of average wages in the production function requires an additional instrument, which makes the approach of Crepon et al. (2002) less attractive, certainly to us given that we only have one instrument available. 


\section{Data}

In this paper we use two distinct data sets: balance-sheet data and linked employer employee data (LEED), which are merged together for the purpose of the analysis. The LEED firm sample we use is uniquely suited for the methodology described in Section 3 as we observe all employees in a given firm, which allows us to precisely capture worker heterogeneity within firms. While worker-level wages and a four-digit ISCO occupational classification are available in the LEED sample, we obtain total staff costs and company performance indicators from balance sheet data.

Specifically, the company-level balance-sheet annual data come from the ASPEKT commercial database, which is a Czech source for the Amadeus EU-wide data and is widely used in empirical research (e.g., Hanousek et al., 2007; Hanousek et al., 2009). The data provide us with information on turnover, total assets, intangible and tangible fixed assets, production, value added, staff costs, operation profit, and liabilities. A full sample comprises information about more than 100,000 companies from all sectors during the period 1999-2006, which is more than 300,000 firm-year observations in total. Furthermore, the ASPEKT data provide information on companies' ownership structure and, thus, allow one to identify foreign-owned companies. We interpret a company as foreign-owned if it has at least $10 \%$ of its equity owned by a foreign investor. ${ }^{15}$ Unfortunately, foreign-ownership information is available only for a limited sub-sample.

For employee data we use a national employer survey, the Information System on Average Earnings (ISAE), from the period 1999-2006. The enterprise survey is conducted by a private agency on behalf of the Czech Ministry of Labour and Social Affairs and firm response is mandatory as the data correspond to the Czech input into the EU-wide Structure of Earnings Survey. The data contain hourly wages, education, age, and a detailed occupational classification for each worker employed in the sampled firms, which also report their total employment and industry (using the NACE classification). The wage records are drawn directly from firms' personnel databases and the definition of hourly wage is detailed and fully consistent across firms; it includes total yearly cash compensation and bonuses divided by total hours worked for that year. The data thus provide precise information on both four-digit-occupation employment and wage structure of Czech firms.

Due to different size and coverage of these two data sets, our merged sample is composed only of 12,951 firm-year observations in total, coming from 3,247 unique firms. ${ }^{16}$ We

15 This threshold is used also in the official definition of FDI by the Czech National Bank and in firmlevel studies by Damijan et al. (2003b), Javorcik (2004), Stančík (2007), or Jurajda and Stančík (2009).

16 We use this merged data, which combines occupational structure with company performance indicators, for most of our analysis. However, we also estimate log-wage Mincerian wage regressions on the full ISAE sample, which is based on well-defined stratified random sampling and, as such, representative of the whole Czech enterprise sector. We do not use the ISAE sampling weights in our regression analysis as under the assumption that regression coefficients are identical across sampling strata, both OLS and WLS (weighted least squares) estimators are consistent, and OLS is efficient. 
perform several data cleaning procedures and consistency checks on this dataset. ${ }^{17}$ Moreover, we analyze only large firms as the content of 'organizational' occupations may not be clearly delineated in smaller companies; as a result, firms with yearly turnover of less than EUR 2 mil. are omitted. Our final sample thus consists of 2,218 firms over the period 1999-2006, which makes for over 7,300 firm-year observations, of which 7,030 report our key left-hand-side variable, namely value added. The number of sampled large firms is evenly distributed across years, with the minimum of 825 in 2003 and the maximum of 1,175 in 2005, as shown in Table 2.

Next, the top panel of Table 4 presents descriptive statistics of the two key left-handside variables in our panel data set. The middle panel of the table shows the shares on employment and relative wages of 'organizational' workers. These are identified using the ISCO-88 occupational classification. Specifically, we first group workers into managerial, marketing, administration, IT, R\&D, production and other-service employees (Table 3 for occupation group definitions) and we then combine managerial and marketing employees under the heading of 'organizational' employees. We select a broad group of occupations to correspond to 'organizational' tasks, including not only corporate and general managers, but also a subset of professionals and associate professionals, and some office clerks. ${ }^{18}$ Table 4 implies that this broad group of 'organizational' workers comprises almost $10 \%$ of company workforce in our data and that these workers on average make $13 \%$ more than other employees. Following the share of 'organizational employees' over time, there is a small increase from about 8.8\% in 1999 to 2001 to about $10 \%$ percent after 2003 . The table also offers separate statistics on the share of managerial (MNG) and marketing (MKT) workforce as well as their relative wage. In general, Czech occupational employment structure remains quite stable during our sample period. ${ }^{19}$ Both the share of R\&D workers on enterprise employment and the combined share of managerial and marketing (i.e., 'organizational') workers hovers around $10 \%$. The share of production and other services workers in Czech enterprises is very high at over $70 \%$ while ICT workers represent less than $3 \%$ of all employees.

The bottom panel of Table 4 lists descriptive statistics for key right-hand-side variables (which are used in log form in regressions), namely tangible fixed assets (Intanfa), total hours worked as our measure of aggregate labour inputs (lnemp), and a measure of R\&D assets (Inrndasset) as well as the share of R\&D workers on company employment. Our goal is to measure relative productivities and wages of 'organizational' workers and a standard specification of the value-added regression would control for R\&D capital on top of controlling for total fixed assets. Unfortunately, our balance sheet data do not contain a direct measure of $R \& D$ expenditures or capital. We therefore either simply

17 We drop firms reporting their intangible/tangible/fixed assets to be higher than their total assets or firms with negative assets. Negative or missing values are dropped as well.

18 The details selection of 4-digit ISCO codes has been harmonized for cross-country comparability within the Inno-drive FP7 project of which this study is one part.

19 This assessment is based on the merged data. However, the original ISAE data weighted using firm sampling weights provide a fully consistent picture. 
control for the share of R\&D workers (also provided in the table) or we condition on a measure of R\&D capital suggested by Piekkola (2009). ${ }^{20}$ It turns out that the choice of the R\&D control makes little difference in the estimation of 'organizational' worker effects, which is perhaps not surprising given that the last column of Table 1 suggests that the share of company wage bills in our data spent on remunerating 'organizational' workers is not systematically related at industry level to R\&D expenditures, not even within manufacturing industries in the middle panel of the table. ${ }^{21}$

\section{Results}

Our first descriptive question is to ask what types of companies employ higher shares of 'organizational' workers. Table 5 shows the estimates from a series of simple crosssectional regressions using 2005 data (i.e., the year of our largest cross-section). In a regression without industry dummies in column (1), higher tangible fixed assets ${ }^{22}$ and lower employment are associated with a higher share of 'organizational' workers. Surprisingly, conditional on the firm-level capital and labour controls, R\&D assets are negatively correlated with the share of 'organizational' workers while our NUTS-4 level instrument (coll91) predicts the share of organizational workers strongly with a $t$ ratio of almost 7. Adding industry dummies in column (2) leaves most of the results qualitatively unchanged.

Our data contain a foreign-ownership indicator (defined in Section 4) for about 500 companies a year, i.e., for about a half of the annual merged sample. Furthermore, for companies that are foreign owned, we also observe an indicator for whether the firm corresponds to green-field FDI or whether a domestic firm was taken over by a foreign investor. ${ }^{23}$ Focusing on the subset of companies for which we observe foreign-ownership status in 2005, the last two columns of Table 5 make clear that green-field investments indeed employ higher shares of 'organizational' workers, as expected, while the association is weaker for foreign takeovers.

Next, we turn to the question of whether 'organizational' workers generate higher productivity and are fairly rewarded for their impact on company performance. (Whether the effects operate through 'organizational' intangibles or general human capital is explored later.) Tables 7 and 8 present the basic set of estimates of the value-added

20 Piekkola (2009) approximates company-specific R\&D capital using the perpetual inventory method, using total wage costs of a particular worker group, $R \& D$ workers in our case, to approximate the relevant investments. We have correlated our proxies for R\&D capital with official $R \& D$ expenditure statistics published by the Czech Statistical Office across both NACE two-digit industrial dimension and NUTS three-digit regional dimension. Both correlations exceeded 0.9, suggesting that the proxies do closely relate to the true amount of R\&D spending.

21 For a study carefully measuring both $\mathrm{R} \& \mathrm{D}$ and firm-specific human-capital investment, see Ballota et al. (2001).

22 Adding the logarithm of intangible assets does not result in any additional predictive power.

23 This data was manually collected and was used by Stančík (2010) to estimate FDI spillover effects in the Czech Republic. 
equation (1) and staff-cost equation (2), respectively. All listed specifications control for industry-year or industry dummies depending whether we use panel-data or cross-sectional variation. Comparison of random-effect and fixed-effect estimates suggests that most of the relevant variation occurs in the cross-sectional dimension of the data. The third column of each table therefore presents OLS estimates based on the 2005 cross-section of firms. The share of 'organizational' workers is both economically and statistically significantly related to company value added and staff costs (as are all other control variables). Comparing the relevant estimates from both equations $\left(\beta_{2}\right.$ with $\left.\frac{\alpha_{2}}{\alpha_{1}}\right)$ suggests that 'organizational' workers are not fully rewarded for their relative productivity in terms of their relative pay.

In the last column of each table, we present the instrumental-variable-estimates. ${ }^{24}$ The estimated coefficients of the share of 'organizational' workers grow dramatically, suggesting that measurement error or endogeneity lead to significant underestimation of the effects. Importantly, based on this specification, we cannot reject the equality of relative productivity and relative pay. We have performed a number of robustness checks. First, controlling for more detailed industrial classification and interacting the capital and labour controls with industry dummies (as in Ilmakunnas and Maliranta, 2005) lowers the magnitude of the estimates, but does not change the qualitative picture. These results are available upon request. Second, the instrumental variable strategy is only valid to the extent that companies do not relocate in order to take advantage of higher concentration of skilled workers in some local labour markets. This is particularly likely to be a problem with recent foreign investments into green-field companies. Further, one may consider the case of the capital city of Prague separately. Tables 9 and 10 present results on sub-samples excluding Prague and/or green-fields. While there is some sensitivity, particularly to excluding the capital city, the results are remarkably consistent in confirming equality of relative pay and productivity across various subsamples. Third, to the extent that not all 'organizational' workers are college-educated, instrumenting by historically predetermined accessibility of college education may be changing the interpretation of the coefficients from those pertaining to all 'organizational' workers to those pertaining to only college-educated 'organizational' workers. We have therefore re-estimated all specifications using the share of college-educated 'organizational' workers as our key variable and the results were fully consistent, both quantitatively and qualitatively to those presented in our main result tables. Fourth, we divided the data into low- and high-R\&D-intensity companies and found little sensitivity with respect to this dimension also. Fifth, we have followed Brynjolfsson et al. (2002) and interacted the share of 'organizational' workers with the share of ICT workers (including the base effect of ICT worker share as well). The interaction was never significant either statistically or economically. Fifth, our proxies for organizational and R\&D inputs are only valid for firms that do not outsource their R\&D or management and marketing activities. We have therefore used Input-Output tables to identify industries that purchase significant amounts of $R \& D$ or marketing services from specialized $R \& D$ or marketing firms and we found little sensitivity again. Sixth and final, the main results were not sensitive to

24 The cross-sectional IV strategy does not suffer from weak instruments (the first stage F is over 20) and is not sensitive to the choice of 2005 . 
alternative measures of $R \& D$ inputs (a proxy for $R \& D$ capital vs. the share of $R \& D$ workers on company workforce).

Next, we turn to the important interpretation issue of the extent to which the estimated relative productivity effects correspond to 'organizational' intangibles (in people) versus worker general education levels. To do so, we add a control variable capturing the human-capital content of the company workforce. We first estimate an aggregate Mincerian wage equation with education and experience terms and generate a measure of 'efficiency' hours of company workforce by applying the wage-equation coefficients to weight the shares of company workforce for each education-experience worker type. Our maintained measure of employment is total hours worked. The 'efficiency'-hours-worked measure is always higher compared to the basic hours count and we separately condition on the original logarithm of total hours and on the logarithm of the ratio of 'efficiency' and simple hours worked. This specification leaves the coefficient on total hours (employment) comparable to that from the basic specifications and adds a new variable that captures how much the general-human-capital content of a company's workforce differs relative to hours worked by only elementary educated workers. The worker-type 'efficiency' weights correspond to economy-wide wage returns to education and experience. These results are presented in Table $11 .{ }^{25}$ Clearly, a large part of the previously estimated relative productivity of 'organizational' workers corresponds to the higher general human capital of firms they are employed in. The remaining coefficient for the share of 'organizational' workers is now similar in magnitude to those reported in Ilmakunnas and Piekkola (2010) based on Finnish data and a related, if different, estimation framework. Applying the metric introduced in Section 3, namely the $\varphi$ parameter of relative productivity, 'organizational' workers appear about 50\% more productive compared to the rest of the workforce.

In the next two columns of the table, we ask whether this relative productivity is different for foreign owned companies (by type). Indeed, an interaction of the orgshare variable with an indicator for foreign status is large and statistically significant at the $10 \%$ level. When we attempt to disentangle foreign takeovers from green-field investments, the coefficients are no longer all statistically significant. Nevertheless, the overall pattern of the coefficients suggests that green-fields have both the highest share of 'organizational' workers and also the highest relative productivity of this part of their workforce. In general, the returns to 'organizational' intangibles (in people) appear higher in foreignowned companies.

Finally, we estimate a worker-level Mincerian wage regression to estimate a parameter similar to $\beta_{2}$ from our firm-level equation (2) and to ask whether 'organizational' workers command a higher wage after controlling for their observable individual demographic characteristics such as education and experience. This exercise is complementary to the estimation of equation (2) in that it allows us to differentiate between two explanations for the estimates from firm-level regressions. Specifically, as the identification of productivity differentials is based on an across-firm comparison, the firm-level data

25 We only present the results for value-added specifications (Equation 1) as the conclusion of equality of relative pay and productivity is not affected by including the general human capital control. 
do not allow one to generate conclusive evidence on whether a higher productivity of organization-related workers comes from a higher share of such workers in more productive firms or instead from the higher productivity of organizational workers within firms. Using individual-level wage data, one can shed light on this issue. We use a 2005 cross-section of 956,042 workers from 1,526 Czech companies employing over 100 workers and regress the logarithm of their hourly wage on their education-attainment (9 detailed categories), a quadratic in experience, and a dummy for being classified as 'organizational' worker. The coefficient we obtain is highly statistically significant and quantitatively similar, at 0.22 , to $\beta_{2}$ from our firm-level staff-cost regression. Next, we control for firm fixed effects and ask whether this comparison holds within firms and find that the coefficient does not change at all.

\section{Conclusion}

Using matched employer-employee data from the Czech Republic data augmented with balance-sheet information, this paper produces estimates of the share of 'organizational' workers in Czech companies and asks about their relative productivity and pay. We find the share to be slowly growing over time and to be systematically unrelated to company R\&D levels. We uncover wage differentials that match productivity differentials, consistent with a competitive spot market for 'organizational' workers. Our preferred estimate, based on controlling for company general levels of human capital, suggests that 'organizational' workers are about $50 \%$ more productive than other workers.

We also investigate whether foreign-owned companies exhibit significantly higher shares of 'organizational' workers, which is motivated by both stylized facts from the literature on the performance-ownership nexus and by case studies of management practices of multinationals. For the former, evidence based on large firm-level data from several post-Soviet economies including the Czech Republic suggests that foreign-ownership (takeover) improves the productivity of domestic firms domestically owned firms (e.g., Jurajda and Stancik, 2009) and that domestically owned firms are not catching up to the productivity levels of foreign-owned companies (e.g., Sabirianova et al., 2005). For the latter, business studies of FDI effects in developing economies (see, e.g., a recent summary of several case studies in McKinsey \& Company, 2003) suggest that foreign owners introduce new organizational and managerial skills to domestic markets, stressing company culture and accountability and relying on new performance measurement or incentive structures.

In order to shed further light into the black box of organizational practices of multinationals, we also ask whether they appear to benefit disproportionately (in comparison to domestically owned companies) from their organizational personnel investments. To capture important differences driven by mode of entry of multinationals, we differentiate between foreign-owned green-field investments and foreign takeovers of domestic companies. This is motivated by the findings of the FDI literature, which suggests that the motives for investment as well as the productivity improvements do differ significantly across this distinction (e.g., Helpman et al., 2004). We find that 'organizational' workers' share is indeed higher in green-field foreign investments, consistent with the superior performance of their mother companies, and that these companies feature higher relative productivity of 'organizational' workers as well. 
Much remains in terms of future work to generate more reliable estimates of the relative productivity of organization-related workers. First, the perfect substitution assumption used in this study ought to be relaxed in future work. Second, larger and better data (including better R\&D expenditure measures and better information on other types of intangible inputs) can be used to assess the relative importance of various forms of intangible capital in industries characterized by different technology (change) and different levels of competition. Specifically, future work can combine Community Innovation Survey data with linked employer-employee data to ask about the relationship between company workforce occupational structure and types of innovation activities. The value of the present paper is in illustrating the application of the HNT technique for the organizational-capital literature and in suggesting that the typical results may be quite sensitive to cross-sectional instrumental variable strategies, which are based on strong assumptions, but also provide a transparent insight into the source of identification.

\section{References}

Aubert P. (2003), "Productivity, Wage and Demand for Elder Workers; an Examination of French Matched Employer-Employee Data." INSEE Working Paper.

Ballota, G., Fakhfakha, F., Taymazb, E. (2001), "Firms' Human Capital, R\&D and Performance: a Study on French and Swedish Firms." Labour Economics, 8 (4), pp. 443-462.

Bontempi, M. E., Mairesse, J. (2008), "Intangible Capital and Productivity: An Exploration on a Panel of Italian Manufacturing Firms." NBER Working Paper No. 14108.

Brynjolfsson, E., Hitt, L.M., Yang, S. (2002), "Intangible Assets: Computers and Organizational Capital." Brookings Papers on Economic Activity, 1, pp. 137-181.

Crepon, B., Deniau, N., Perez-Duarte, S. (2002), "Wages, Productivity, and Worker Characteristics: A French Perspective." Mimeo.

Corrado, C. A., Hulten C. R. (2010), "How to Measure a 'Technological Revolution'?" American Economic Review, 100, pp. 99-104.

Damijan, J. P., Knell, M., Majcen, B., Rojec, M. (2003a), "The Role of FDI, R\&D Accumulation and Trade in Transferring Technology to Transition Countries: Evidence from Firm Panel Data for Eight Transition Countries." Economic Systems, 27(2), pp. 189-204.

Damijan, J. P., Knell, M., Majcen, B., Rojec, M. (2003b), “Technology Transfer through FDI in Top-10 Transition Countries: How Important are Direct Effects, Horizontal and Vertical Spillovers?" WDI Working Paper, p. 549.

Eriksson, T. (2005), "Managerial Pay and Executive Turnover in the Czech and Slovak Republics." Economics of Transition, 13 (4), pp. 659-677.

Galuscak, K., Lizal, L. (2011), "The Impact of Capital Measurement Error Correction on Firm-Level Production Function Estimation." Czech National Bank Working Papers 2011/09.

Griliches, Z., Mairesse, J. (1997), "Production Functions: the Search for Identification." In Strom, S., ed., Essays in Honour of Ragnar Frisch. Econometric Society Monograph D Series. Cambridge Univ. Press, Cambridge.

Hanousek, J., Kočenda, E., Švejnar, J. (2007), "Origin and Concentration: Corporate Ownership, Control and Performance." Economics of Transition, 15(1), pp. 1-31.

Hanousek, J., Kočenda, E., Švejnar, J. (2009), "Divestitures, Privatization and Corporate Performance in Emerging Markets." Economics of Transition, 17(1), pp. 43-73.

Hellerstein, J. K., Neumark, D., Troske, K. R. (1999), "Wages, Productivity, and Worker Characteristics: Evidence from Plant-Level Production Functions and Wage Equations." Journal of Labor Economics, 17(3), pp. 409-446. 
Helpman, E., Melitz, M. J., Yeaple, S. R. (2004), "Export versus FDI with Heterogeneous Firms." American Economic Review, 94(1), pp. 300-316.

IImakunnas, P., Maliranta, M. (2005), "Technology, Labour Characteristics and Wage-productivity Gaps." Oxford Bulletin of Economics and Statistics, 67 (5), pp. 623-645.

IImakunnas, P., Piekkola, H. (2010), "Intangible Investment in People and Productivity." Innodrive Working Paper No. 8.

Javorcik, B. S. (2004), "Does Foreign Direct Investment Increase the Productivity of Domestic Firms? In Search of Spillovers through Backward Linkages." American Economic Review, 94(3), pp. 605-627.

Jona-Lasinio, C., lommi, M., Manzocchi, S. (2011), "Intangible Capital and Productivity Growth in European Countries." Innodrive Working Paper.

Jurajda, Š., Paligorova, T. (2009), "Czech Female Managers and their Wages." Labour Economics, pp. 342-351.

Jurajda, Š., Stančík, J. (2009), "Foreign Ownership and Corporate Performance: The Czech Republic at EU Entry." CERGE-EI Working Paper, 389.

Jurajda, Š., Terrell, K. (2009), "Regional Unemployment and Human Capital in Transition." Economics of Transition, 17 (2), pp. 241-274.

Kinoshita, Y. (2000), "R\&D and Technology Spillovers via FDI: Innovation and Absorptive Capacity." WDI Working Paper, p. 349.

Levinsohn, J., Petrin, A. (2003), "Estimating Production Functions Using Inputs to Control for Unobservables." Review of Economic Studies, 70(2), pp. 317-342.

McGrattan, E. R., Prescott, E. C. (2008), "Technology Capital and the U.S. Current Account." NBER Working Paper No. 13983.

McKinsey \& Company (2003), New Horizons: Multinational Company Investment in Developing Economies.

Miyagawa, T., Kim, Y. (2008), "Measuring Organization Capital in Japan: An Empirical Assessment Using Firm-Level Data." Seoul Journal of Economics, 21(1), pp. 169-189.

Olley, G. S., Pakes, A. (1996), "The Dynamics of Productivity in the Telecommunications Equipment Industry." Econometrica, 64(6), pp. 1263-1297.

Parotta, P., Pozzoli, D., Pytlikova, M. (2010a), "Does Labour Diversity Affect Firm Productivity?" ASB Working Paper No. 10-12.

Parotta, P., Pozzoli, D., Pytlikova, M. (2010b), “The Nexus between Labor Diversity and Firm's Innovation." ASB Working Paper No. 10-15.

Piekkola, H. (2009), "Intangibles: Can They Explain the Unexplained?" Innodrive Working Paper № 2.

Prescott, E. C., Visscher, M. (1980), "Organization Capital.” Journal of Political Economy, 88, pp. 446-461.

Sabirianova, K., Svejnar, J., Terrell K. (2005), "Foreign Investment, Corporate Ownership, and Development: Are Firms in Emerging Markets Catching Up to the World Standard?" CEPR Discussion Paper No. 4868.

Srholec, M. (2009), "Does Foreign Ownership Facilitate Cooperation on Innovation? Firm-level Evidence from the Enlarged European Union." European Journal of Development Research, 21(1), pp. 47-62.

Stančík, J. (2007), "Horizontal and Vertical FDI Spillovers: Recent Evidence from the Czech Republic." CERGE-El Working Paper, p. 340.

Stančík, J. (2010), "FDI Spillovers in the Czech Republic: Takeovers versus Greenfields." In: Keereman, F., Szekely, I., eds. Five Years of an Enlarged EU: A Positive Sum Game. Springer, pp. 33-54.

Van Ours, J. C., Stoeldraijer, L. (2010), "Age, Wage and Productivity." CEPR Discussion Paper No. 7713. 


\section{Appendix}

\section{Figures and Tables}

Figure 1

International Comparison of Total R\&D Expenditure (GERD)

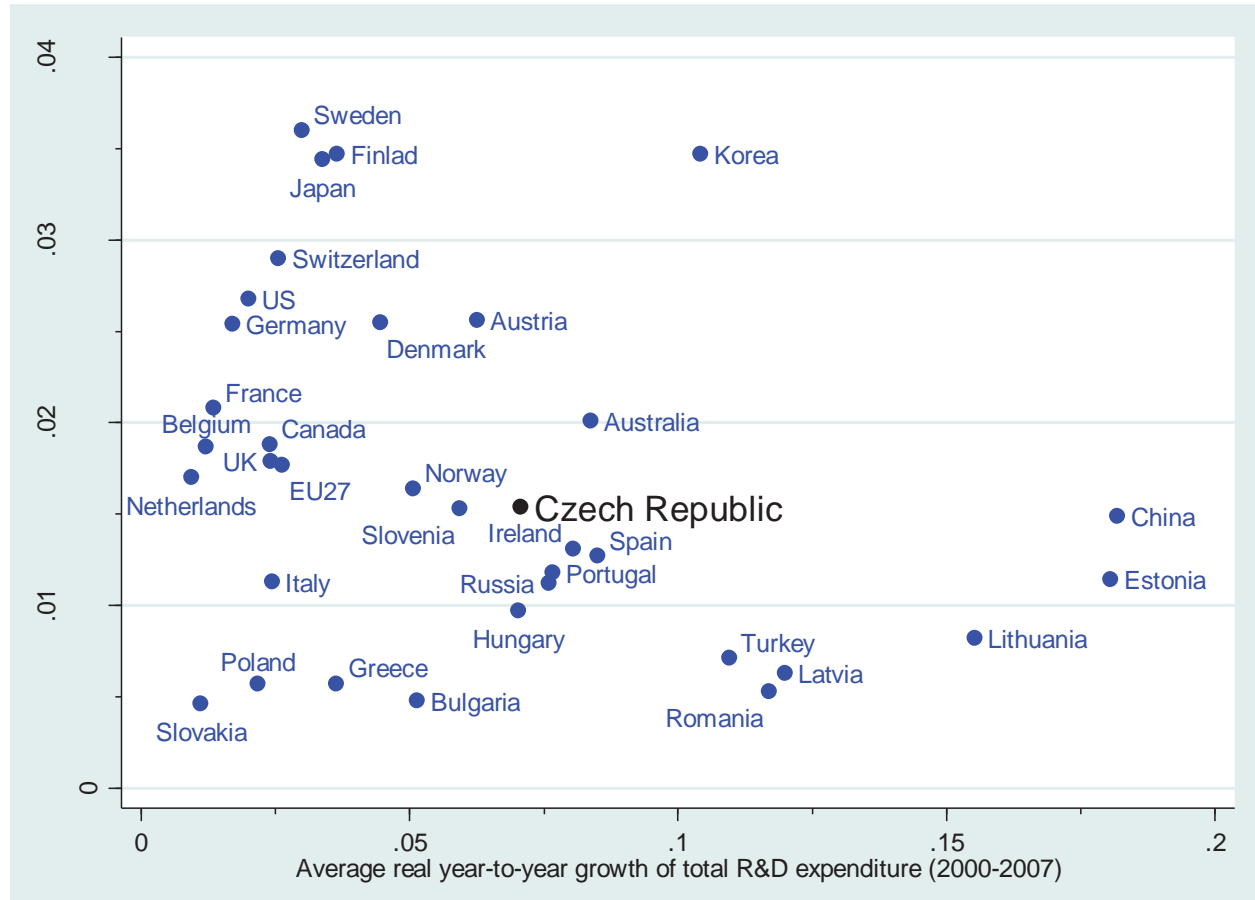

Source: Czech Statistical Office. 
Table 1

\section{R\&D and 'Organizational Worker' Expenditures by Sectors}

The $\%$ share of $R \& D$ expenditures relative to the size of a sector measured by net fixed assets. The last two columns present the \% shares of compensation for managerial (MNG) and 'organizational workers' (ORG, defined in Section 4) on total company compensation.

\begin{tabular}{|l|r|r|r|r|r|r|}
\hline & \multicolumn{2}{|c|}{ all companies } & \multicolumn{2}{|c|}{ foreign } & MNG & ORG \\
\hline NACE I year & 2000 & 2006 & 2000 & 2006 & 2006 & 2006 \\
\hline Agriculture, Forestry and Fishing & 0.03 & 0.04 & 0.01 & 0.01 & 9.77 & 9.92 \\
\hline Mining and Quarrying & 0.03 & 0.04 & 0.00 & 0.00 & 5.54 & 5.63 \\
\hline Food, Beverages and Tobacco Industry & 0.06 & 0.09 & 0.02 & 0.06 & 14.12 & 14.60 \\
\hline Textile, Clothing, Leather and Footwear Industry & 0.20 & 0.43 & 0.00 & 0.10 & 7.79 & 8.27 \\
\hline Wood-processing and Paper Industry & 0.00 & 0.01 & 0.00 & 0.00 & 9.32 & 9.63 \\
\hline Publishing and Printing Industry & 0.01 & 0.06 & 0.00 & 0.00 & 12.18 & 12.88 \\
\hline $\begin{array}{l}\text { Petrochemical, Chemical and Pharmaceutical } \\
\text { Industry }\end{array}$ & 0.77 & 2.90 & 0.22 & 2.60 & 12.48 & 12.65 \\
\hline Rubber and Plastic Industry & 0.47 & 0.91 & 0.11 & 0.59 & 7.72 & 7.98 \\
\hline Non-metallic Mineral Industry & 0.18 & 0.32 & 0.09 & 0.05 & 10.01 & 10.23 \\
\hline Metal Processing Industry & 0.31 & 0.28 & 0.03 & 0.09 & 7.50 & 7.67 \\
\hline Engineering Industry & 1.44 & 1.60 & 0.22 & 0.70 & 9.48 & 9.89 \\
\hline Electrical Industry & 0.84 & 1.18 & 0.19 & 0.52 & 7.92 & 8.22 \\
\hline $\begin{array}{l}\text { Manufacture of computer, electronic and optical } \\
\text { products }\end{array}$ & 1.59 & 3.79 & 0.42 & 2.61 & 11.91 & 12.33 \\
\hline Automotive Industry & 3.63 & 3.16 & 2.86 & 2.65 & 9.75 & 9.99 \\
\hline Manufacturing of furniture & 0.59 & 0.23 & 0.00 & 0.06 & 8.31 & 8.67 \\
\hline Electricity, Gas and Water Supply & 0.00 & 0.01 & 0.00 & 0.00 & 13.47 & 13.60 \\
\hline Construction & 0.15 & 0.19 & 0.02 & 0.01 & 20.08 & 20.30 \\
\hline $\begin{array}{l}\text { Wholesale and Retail Trade, Hotels and } \\
\text { Restaurants }\end{array}$ & 0.03 & 0.08 & 0.00 & 0.03 & 14.34 & 20.88 \\
\hline Transport, Storage and Communication & 0.01 & 0.02 & 0.00 & 0.02 & 5.98 & 6.15 \\
\hline Financial Intermediation & 0.00 & 0.55 & 0.00 & 0.51 & 64.75 & 65.51 \\
\hline Business Services & 0.14 & 0.22 & 0.02 & 0.06 & 17.85 & 19.80 \\
\hline Community, Social and Personal Service Activities & 0.02 & 0.01 & 0.00 & 0.00 & 14.73 & 16.02 \\
\hline Total & 0.16 & 0.27 & 0.06 & 0.16 & 15.35 & 16.21 \\
\hline
\end{tabular}

Note: Foreign firms have more than $50 \%$ of voting rights held by foreign investors. Source: Czech Statistical Office, ISAE Data - own calculations.

Table 2

Firm Data Sources. The table presents the composition of our data by sources and years.

\begin{tabular}{|l|c|c|c|}
\hline & Aspekt & ISAE & merged \\
\hline $\mathbf{1 9 9 9}$ & 9337 & & 843 \\
\hline $\mathbf{2 0 0 0}$ & 11097 & 2095 & 923 \\
\hline $\mathbf{2 0 0 1}$ & 14361 & 2640 & 891 \\
\hline $\mathbf{2 0 0 2}$ & 35879 & 3086 & 835 \\
\hline $\mathbf{2 0 0 3}$ & 59366 & 3006 & 825 \\
\hline $\mathbf{2 0 0 4}$ & 73867 & 3596 & 968 \\
\hline $\mathbf{2 0 0 5}$ & 66360 & 4073 & 1175 \\
\hline $\mathbf{2 0 0 6}$ & 42150 & 2997 & 935 \\
\hline $\mathbf{2 0 0 7}$ & & 3579 & \\
\hline
\end{tabular}


Table 3

Occupational Classification of Non-production Workers

\begin{tabular}{|c|c|}
\hline Occupation of non-production worker & worker group \\
\hline \multicolumn{2}{|l|}{ Manufacturing } \\
\hline Management & Management \\
\hline R\&D & R\&D \\
\hline R\&D superior & R\&D \\
\hline \multicolumn{2}{|l|}{ Supply transport non-prod } \\
\hline \multicolumn{2}{|l|}{ Supply transport non-prod superior } \\
\hline Computer & IT \\
\hline Computer superior & IT \\
\hline \multicolumn{2}{|l|}{ Safety quality maintenance non-prod } \\
\hline Marketing purchases non-prod & Marketing \\
\hline Marketing purchases non-prod superior & Management \\
\hline Administration non-prod & Administration \\
\hline Administration non-prod superior & Administration \\
\hline \multicolumn{2}{|l|}{ Finance admin non-prod } \\
\hline Finance admin non-prod superior & Management \\
\hline Personnel management non-prod & Administration \\
\hline \multicolumn{2}{|l|}{ Cleaner garbage collectors messengers } \\
\hline \multicolumn{2}{|l|}{ Services } \\
\hline \multicolumn{2}{|l|}{ Media } \\
\hline Computer processing services & IT \\
\hline Computer processing services superior & IT \\
\hline \multicolumn{2}{|l|}{ Salesperson contract work services } \\
\hline \multicolumn{2}{|l|}{ Warehouse transport services } \\
\hline \multicolumn{2}{|l|}{ Maintenance gardening forest services } \\
\hline \multicolumn{2}{|l|}{$\begin{array}{l}\text { Teacher counselling social science } \\
\text { professionals }\end{array}$} \\
\hline \multicolumn{2}{|l|}{ Hotel restaurants } \\
\hline \multicolumn{2}{|l|}{ Hotel restaurants superior } \\
\hline \multicolumn{2}{|l|}{ Social and personal care } \\
\hline \multicolumn{2}{|l|}{ Health sector } \\
\hline \multicolumn{2}{|l|}{ Forwarder services } \\
\hline \multicolumn{2}{|l|}{ Purchases and sales services } \\
\hline \multicolumn{2}{|l|}{ Insurance worker } \\
\hline \multicolumn{2}{|l|}{ Insurance worker superior } \\
\hline \multicolumn{2}{|l|}{ Small business manager } \\
\hline \multicolumn{2}{|l|}{ Finance services } \\
\hline Finance services superior & Management \\
\hline \multicolumn{2}{|l|}{ Marketing services } \\
\hline Marketing services superior & Marketing \\
\hline R\&D worker services & $R \& D$ \\
\hline Personnel project manag services & Administration \\
\hline Personnel project manag services superior & Management \\
\hline \multicolumn{2}{|l|}{ Administration services } \\
\hline Administration services & Management \\
\hline
\end{tabular}


Table 4

Summary Statistics

\begin{tabular}{|l|r|r|r|c|}
\hline & Mean & \multicolumn{1}{|c|}{ Std } & Median & N \\
\hline Value Added (ths. EUR) & 11041 & 50411 & 2304 & 7028 \\
\hline log(VA) & 7.8 & 1.6 & 7.7 & 7028 \\
\hline Staff Costs (ths. EUR) & 7107 & 35961 & 2048 & 7189 \\
\hline log(SC) & 7.7 & 1.4 & 7.6 & 7189 \\
\hline ORGshare & 0.094 & 0.135 & 0.054 & 7179 \\
\hline MNGshare & 0.089 & 0.132 & 0.050 & 7179 \\
\hline MKTshare & 0.006 & 0.019 & 0.000 & 7179 \\
\hline ORG-RelatWage & 0.133 & 0.121 & 0.104 & 7186 \\
\hline MNG-RelatWage & 0.127 & 0.118 & 0.099 & 7186 \\
\hline MKT-RelatWage & 0.006 & 0.019 & 0.000 & 7186 \\
\hline Tangible FA (ths. EUR) & 26051 & 167894 & 3094 & 7155 \\
\hline Hours & 812697 & 3336557 & 311804 & 7189 \\
\hline RDasset (ths. EUR) & 2953 & 13234 & 520 & 7189 \\
\hline RDshare & .088 & .085 & .077 & 7179 \\
\hline
\end{tabular}

Table 5

The Share of 'Organizational' Workers

The dependent variable is orgshare.

\begin{tabular}{|c|c|c|c|c|}
\hline & (1) & (2) & (3) & (4) \\
\hline const & $\begin{array}{c}0.462^{* \star *} \\
(0.063)\end{array}$ & $\begin{array}{c}0.372^{* * *} \\
(0.050)\end{array}$ & $\begin{array}{c}0.261^{* * *} \\
(0.076)\end{array}$ & $\begin{array}{c}0.293^{* * *} \\
(0.082)\end{array}$ \\
\hline Intanfa & $\begin{array}{l}0.009^{* *} \\
(0.004)\end{array}$ & $\begin{array}{c}0.011^{* * *} \\
(0.004)\end{array}$ & $\begin{array}{l}-0.003 \\
(0.005)\end{array}$ & $\begin{array}{l}-0.003 \\
(0.005)\end{array}$ \\
\hline Inemp & $\begin{array}{c}-0.032^{\star * *} \\
(0.007)\end{array}$ & $\begin{array}{c}-0.031^{* * *} \\
(0.006)\end{array}$ & $\begin{array}{l}-0.012 \\
(0.008)\end{array}$ & $\begin{array}{l}-0.015^{*} \\
(0.008) \\
\end{array}$ \\
\hline Inrndasset & $\begin{array}{c}-0.011^{* * *} \\
(0.002)\end{array}$ & $\begin{array}{c}-0.002 \\
(0.002)\end{array}$ & $\begin{array}{c}-0.005^{\star *} \\
(0.003)\end{array}$ & $\begin{array}{l}-0.005 \\
(0.003) \\
\end{array}$ \\
\hline coll91 & $\begin{array}{c}0.119^{\star * *} \\
(0.016)\end{array}$ & $\begin{array}{c}0.054^{* * *} \\
(0.013)\end{array}$ & $\begin{array}{c}0.080^{* * *} \\
(0.017)\end{array}$ & $\begin{array}{c}0.091^{* * *} \\
(0.020)\end{array}$ \\
\hline foreign & & & $\begin{array}{c}0.014 \\
(0.009)\end{array}$ & \\
\hline greenfield & & & & $\begin{array}{l}0.035^{\star *} \\
(0.017)\end{array}$ \\
\hline takeover & & & & $\begin{array}{c}0.013 \\
(0.010) \\
\end{array}$ \\
\hline dummies & & Sector & sector & sector \\
\hline $\mathbf{N}$ & 1133 & 1133 & 510 & 446 \\
\hline$R^{2}$ & 0.218 & 0.492 & 0.491 & 0.526 \\
\hline
\end{tabular}

Note: Industrial sectors are merged into groups defined in Table 6 . coll91 measures the availability of college education in each NUTS4 area as of 1991.

Robust standard errors are in parentheses; significance at $1 \%, 5 \%$, and $10 \%$ level is denoted by ${ }^{* *},{ }^{* *}$, and ${ }^{*}$, respectively. 
Table 6

\section{Industry Classification}

\begin{tabular}{|c|l|l|}
\hline & Industry & NACE Rev. 1 \\
\hline $\mathbf{1}$ & $\begin{array}{l}\text { Service, consumer non-durables: food, tobacco, textiles, } \\
\text { apparel, leather, hotels, entertainment, and utilities }\end{array}$ & $\begin{array}{l}\text { DA, DB, DC, DE (excl. 21), DM } \\
\text { (355), DN (361, 362, excl. 3611 } \\
\text { and 3612), E, H }\end{array}$ \\
\hline $\mathbf{2}$ & $\begin{array}{l}\text { Consumer durables: cars, TVs, furniture, household appliances, } \\
\text { transportation, toys, and sports }\end{array}$ & $\begin{array}{l}\text { DN (3611, 3612, excl. 361 and } \\
\text { 362), DM (354), DL (322, 323) }\end{array}$ \\
\hline $\mathbf{3}$ & $\begin{array}{l}\text { Other manufacturing: metal, trucks, planes, office furniture, and } \\
\text { paper }\end{array}$ & $\begin{array}{l}\text { DD, DE (excl. 22), DJ, DK, DM } \\
\text { (excl. 354 and 355) }\end{array}$ \\
\hline $\mathbf{4}$ & Energy, oil, gas, and coal extraction and products & DF \\
\hline $\mathbf{5}$ & Chemicals and allied products & DG (excl. 244), DH \\
\hline $\mathbf{6}$ & $\begin{array}{l}\text { Business equipment: computers, software, and electronic } \\
\text { equipment }\end{array}$ & DL (30, 31, 332-335), K (721-724) \\
\hline $\mathbf{7}$ & Telecom, telephone and television transmission & I (642) \\
\hline $\mathbf{8}$ & Wholesale, retail, and some services, (laundries, repair shops) & G, O (930) \\
\hline $\mathbf{9}$ & Healthcare, medical equipment, and drugs & DG (244), DL (331), N \\
\hline $\mathbf{1 0}$ & Money, finance & J, K (excl. 721-724) \\
\hline $\mathbf{1 1}$ & $\begin{array}{l}\text { Other: construction, mining, transportation, non-metallic mineral } \\
\text { products, hotels, restaurants, transportation, utility }\end{array}$ & DI, F, I (excl. 642) \\
\hline
\end{tabular}

Table 7

\section{Value Added - Various Estimation Techniques}

The dependent variable is In VALUE ADDED.

\begin{tabular}{|l|c|c|c|c|}
\hline & RE & FE & OLS (2005) & IV (2005) \\
\hline coll91 & & & & $0.060^{* * *}$ \\
& & & & $(0.013)$ \\
\hline F & & & & 22.22 \\
\hline orgshare & $0.335^{* *}$ & -0.095 & $1.482^{* * *}$ & $8.836^{* * *}$ \\
& $(0.161)$ & $(0.180)$ & $(0.284)$ & $(1.987)$ \\
\hline Intanfa & $0.242^{* * *}$ & $0.159^{* * *}$ & $0.151^{* * *}$ & $0.100^{* * *}$ \\
& $(0.017)$ & $(0.024)$ & $(0.020)$ & $(0.037)$ \\
\hline Inemp & $0.528^{* * *}$ & $0.304^{* * *}$ & $0.856^{* * *}$ & $1.002^{* * *}$ \\
& $(0.034)$ & $(0.040)$ & $(0.035)$ & $(0.071)$ \\
\hline Inrndasset & $0.027^{* * *}$ & -0.009 & $0.045^{* * *}$ & $0.082^{* * *}$ \\
& $(0.009)$ & $(0.013)$ & $(0.010)$ & $(0.018)$ \\
\hline dummies & year*sector & year*sector & sector & sector \\
\hline $\mathbf{N}$ & 6975 & 6975 & 1110 & 1105 \\
\hline $\mathbf{X}^{2}$ & 12313.718 & & & 253.946 \\
\hline $\mathbf{F}$ & & 84.912 & 422.643 & 0.619 \\
\hline $\boldsymbol{R}^{2}$ & & 0.248 & 0.828 & \\
\hline
\end{tabular}

Note: Sectors are merged into groups defined in Table 6. Robust standard errors clustered at company level are in parentheses; significance at $1 \%, 5 \%$, and $10 \%$ level is denoted by ${ }^{* * *},{ }^{* *}$, and ${ }^{*}$, respectively. 
Table 8

Staff Costs - Various Estimation Techniques

The dependent variable is In STAFF COSTS.

\begin{tabular}{|c|c|c|c|c|}
\hline & RE & FE & OLS (2005) & IV (2005) \\
\hline coll91 & & & & $\begin{array}{c}0.054^{\star * *} \\
(0.013)\end{array}$ \\
\hline $\mathbf{F}$ & & & & 18.04 \\
\hline orgshare & $\begin{array}{c}0.422^{* * *} \\
(0.137)\end{array}$ & $\begin{array}{c}0.071 \\
(0.153)\end{array}$ & $\begin{array}{l}1.031^{* * *} \\
(0.209)\end{array}$ & $\begin{array}{c}7.401^{* * *} \\
(1.745)\end{array}$ \\
\hline Intanfa & $\begin{array}{c}0.167^{\star * \star} \\
(0.014)\end{array}$ & $\begin{array}{c}0.139^{* * *} \\
(0.021)\end{array}$ & $\begin{array}{c}0.052^{* \star *} \\
(0.010)\end{array}$ & $\begin{array}{l}-0.015 \\
(0.031)\end{array}$ \\
\hline Inemp & $\begin{array}{c}0.605^{\star * *} \\
(0.031)\end{array}$ & $\begin{array}{c}0.349^{* * *} \\
(0.038)\end{array}$ & $\begin{array}{c}0.906^{* * *} \\
(0.020)\end{array}$ & $\begin{array}{l}1.072^{* * *} \\
(0.064)\end{array}$ \\
\hline Inrndasset & $\begin{array}{c}0.025^{\star * *} \\
(0.007)\end{array}$ & $\begin{array}{l}-0.003 \\
(0.012)\end{array}$ & $\begin{array}{c}0.029^{\star * *} \\
(0.008)\end{array}$ & $\begin{array}{c}0.057^{* * *} \\
(0.015)\end{array}$ \\
\hline dummies & year*sector & year*sector & sector & sector \\
\hline $\mathbf{N}$ & 7132 & 7132 & 1135 & 1130 \\
\hline$x^{2}$ & 73749.816 & & & \\
\hline $\mathbf{F}$ & & 211.496 & 757.314 & 348.161 \\
\hline$R^{2}$ & & 0.526 & 0.893 & 0.673 \\
\hline
\end{tabular}

Note: Sectors are merged into groups defined in Table 6. Robust standard errors clustered at company level are in parentheses; significance at $1 \%, 5 \%$, and $10 \%$ level is denoted by ${ }^{* *}{ }^{* *}$, and ${ }^{*}$, respectively. 
Table 9

Robustness Tests with Value Added - Subsamples

The dependent variable is In VALUE ADDED.

\begin{tabular}{|c|c|c|c|c|c|c|}
\hline & \multicolumn{2}{|c|}{ without Prague } & \multicolumn{2}{|c|}{ without greenfields } & \multicolumn{2}{|c|}{$\begin{array}{c}\text { without Prague \& } \\
\text { greenfields }\end{array}$} \\
\hline & RE & IV (2005) & RE & IV (2005) & RE & IV (2005) \\
\hline coll91 & & $\begin{array}{l}0.048^{* * *} \\
(0.016)\end{array}$ & & $\begin{array}{l}0.052^{* *} \\
(0.013)\end{array}$ & & $\begin{array}{l}0.045^{\star \star \star} \\
(0.017)\end{array}$ \\
\hline $\mathbf{F}$ & & 8.39 & & 16.43 & & 7.40 \\
\hline orgshare & $\begin{array}{l}0.238 \\
(0.185)\end{array}$ & $\begin{array}{l}4.764^{* *} \\
(2.139)\end{array}$ & $\begin{array}{l}0.281^{*} \\
(0.161)\end{array}$ & $\begin{array}{l}9.061^{* * *} \\
(2.387)\end{array}$ & $\begin{array}{l}0.209 \\
(0.186)\end{array}$ & $\begin{array}{l}5.400^{\star *} \\
(2.454)\end{array}$ \\
\hline Intanfa & $\begin{array}{l}0.245^{* * *} \\
(0.018)\end{array}$ & $\begin{array}{l}0.112^{\star \star *} \\
(0.030)\end{array}$ & $\begin{array}{l}0.243^{* * *} \\
(0.017)\end{array}$ & $\begin{array}{l}0.055 \\
(0.041)\end{array}$ & $\begin{array}{l}0.243^{* * *} \\
(0.018)\end{array}$ & $\begin{array}{l}0.101^{* * *} \\
(0.034)\end{array}$ \\
\hline Inemp & $\begin{array}{l}0.519^{* * *} \\
(0.037)\end{array}$ & $\begin{array}{l}0.952^{* \star *} \\
(0.071)\end{array}$ & $\begin{array}{l}0.513^{* * *} \\
(0.035)\end{array}$ & $\begin{array}{l}1.059^{* * *} \\
(0.084)\end{array}$ & $\begin{array}{l}0.508^{* * *} \\
(0.037)\end{array}$ & $\begin{array}{l}0.981^{* * *} \\
(0.083)\end{array}$ \\
\hline Inrndasset & $\begin{array}{l}0.041^{* * *} \\
(0.009)\end{array}$ & $\begin{array}{l}0.065^{\star * *} \\
(0.015)\end{array}$ & $\begin{array}{l}0.030^{* * *} \\
(0.009)\end{array}$ & $\begin{array}{l}0.088^{* * *} \\
(0.020)\end{array}$ & $\begin{array}{l}0.043^{* * *} \\
(0.010)\end{array}$ & $\begin{array}{l}0.062^{* * *} \\
(0.016)\end{array}$ \\
\hline dummies & year*sector & sector & year*sector & sector & year*sector & sector \\
\hline $\mathbf{N}$ & 6040 & 940 & 6616 & 1034 & 5797 & 892 \\
\hline$x^{2}$ & 16867.932 & & 17295.394 & & 15758.616 & \\
\hline $\mathbf{F}$ & & 332.181 & & 198.180 & & 275.559 \\
\hline $\boldsymbol{R}^{2}$ & & 0.813 & & 0.601 & & 0.791 \\
\hline
\end{tabular}

Note: Sectors are merged into groups defined in Table 6. Robust standard errors clustered at company level are in parentheses; significance at $1 \%, 5 \%$, and $10 \%$ level is denoted by ${ }^{* * *},{ }^{* *}$, and ${ }^{*}$, respectively. 
Table 10

Robustness Tests for Staff Costs - Subsamples

The dependent variable is In STAFF COSTS.

\begin{tabular}{|l|c|c|c|c|c|c|}
\hline \multirow{2}{*}{} & \multicolumn{2}{|c|}{ without Prague } & \multicolumn{2}{c|}{ without greenfields } & \multicolumn{2}{c|}{$\begin{array}{c}\text { without Prague \& } \\
\text { greenfields }\end{array}$} \\
\hline coll91 & RE & IV (2005) & RE & IV (2005) & RE & IV (2005) \\
\hline & & $0.043^{* * *}$ & & $0.046^{* *}$ & & $0.041^{* *}$ \\
\hline F & $(0.016)$ & & $(0.013)$ & & $(0.016)$ \\
\hline orgshare & 0.151 & $4.857^{* *}$ & $0.289^{* *}$ & $7.680^{* * *}$ & 0.121 & $5.200^{* *}$ \\
& $(0.161)$ & $(2.036)$ & $(0.136)$ & $(2.192)$ & $(0.164)$ & $(2.326)$ \\
\hline Intanfa & $0.162^{* * *}$ & 0.006 & $0.169^{* * *}$ & -0.045 & $0.162^{* * *}$ & -0.004 \\
& $(0.014)$ & $(0.031)$ & $(0.014)$ & $(0.040)$ & $(0.015)$ & $(0.037)$ \\
\hline Inemp & $0.605^{* * *}$ & $1.016^{* * *}$ & $0.596^{* * *}$ & $1.109^{* * *}$ & $0.595^{* * *}$ & $1.031^{* * *}$ \\
& $(0.033)$ & $(0.073)$ & $(0.031)$ & $(0.082)$ & $(0.034)$ & $(0.088)$ \\
\hline Inrndasset & $0.038^{* * *}$ & $0.048^{* * *}$ & $0.025^{* * *}$ & $0.062^{* * *}$ & $0.038^{* * *}$ & $0.046^{* * *}$ \\
& $(0.008)$ & $(0.012)$ & $(0.008)$ & $(0.017)$ & $(0.008)$ & $(0.013)$ \\
\hline dummies & year*sector & sector & year*sector & sector & year*sector & sector \\
\hline N & 6159 & 963 & 6771 & 1059 & 5916 & 915 \\
\hline $\mathbf{X}^{\mathbf{2}}$ & 81352.949 & & 31155.669 & & 76247.473 & \\
\hline F & & 467.516 & & 1117.178 & & 414.466 \\
\hline $\boldsymbol{R}^{2}$ & & 0.837 & & 0.637 & & 0.813 \\
\hline
\end{tabular}

Note: Sectors are merged into groups defined in Table 6. Robust standard errors clustered at company level are in parentheses; significance at $1 \%, 5 \%$, and $10 \%$ level is denoted by ${ }^{* * *}$, ${ }^{* *}$, and ${ }^{*}$, respectively. 
DOI: 10.18267/j.pep.442

Table 11

Value Added - Controlling for General Human Capital in 2005 Cross-section

The dependent variable is In VALUE ADDED.

\begin{tabular}{|c|c|c|c|}
\hline & (1) & (2) & (3) \\
\hline const & $\begin{array}{c}-5.376^{* * *} \\
(0.326)\end{array}$ & $\begin{array}{c}-4.681^{* * *} \\
(0.345)\end{array}$ & $\begin{array}{c}-4.719^{* \star *} \\
(0.347)\end{array}$ \\
\hline orgshare & $\begin{array}{l}0.434^{*} \\
(0.260)\end{array}$ & $\begin{array}{c}0.232 \\
(0.228)\end{array}$ & $\begin{array}{c}0.330 \\
(0.238)\end{array}$ \\
\hline orgshare*foreign & & $\begin{array}{l}0.958^{*} \\
(0.542)\end{array}$ & \\
\hline foreign & & $\begin{array}{c}0.208^{\star * *} \\
(0.055)\end{array}$ & \\
\hline orgshare*takeover & & & $\begin{array}{c}0.350 \\
(1.004)\end{array}$ \\
\hline orgshare*greenfield & & & $\begin{array}{c}0.777 \\
(0.603)\end{array}$ \\
\hline greenfield & & & $\begin{array}{c}0.373^{* * *} \\
(0.071)\end{array}$ \\
\hline takeover & & & $\begin{array}{l}0.209^{\star *} \\
(0.087)\end{array}$ \\
\hline Intanfa & $\begin{array}{c}0.140^{* * *} \\
(0.019)\end{array}$ & $\begin{array}{c}0.053^{* * *} \\
(0.019)\end{array}$ & $\begin{array}{c}0.061^{* * *} \\
(0.021)\end{array}$ \\
\hline Inemp & $\begin{array}{l}0.904^{\star * *} \\
(0.033)\end{array}$ & $\begin{array}{c}0.899^{* * *} \\
(0.035)\end{array}$ & $\begin{array}{c}0.896^{* * *} \\
(0.037)\end{array}$ \\
\hline Ineffemp & $\begin{array}{c}3.236^{\star * *} \\
(0.353)\end{array}$ & $\begin{array}{c}2.027^{\star \star \star} \\
(0.275)\end{array}$ & $\begin{array}{c}2.117^{\star \star \star} \\
(0.317)\end{array}$ \\
\hline Inrndasset & $\begin{array}{c}0.010 \\
(0.007) \\
\end{array}$ & $\begin{array}{l}0.013^{*} \\
(0.007) \\
\end{array}$ & $\begin{array}{c}0.013 \\
(0.008)\end{array}$ \\
\hline dummies & sector & sector & Sector \\
\hline N & 1108 & 511 & 447 \\
\hline$R^{2}$ & 0.844 & 0.895 & 0.900 \\
\hline
\end{tabular}

Note: Sectors are merged into groups defined in Table 6. Ineffemp denotes a general human capital control - relative 'efficiency' hours worked. Robust standard errors are in parentheses; significance at 1\%, 5\%, and $10 \%$ level is denoted by ${ }^{* * *},{ }^{* *}$, and ${ }^{*}$, respectively. 